\title{
Facilitating Learning Mathematics Through the Use of Instructional Media
}

\author{
Reylan Capuno ${ }^{1}$, Helen Revalde ${ }^{1}$, Jonathan Olores Etcuban ${ }^{1 *}$, Marvin Aventuna ${ }^{1}$, Gerwine Medio ${ }^{1}$, \\ Rino Anthony Demeterio ${ }^{1}$
}

${ }^{1}$ Cebu Technological University, Cebu City, PHILIPPINES

*CORRESPONDENCE: - joetcuban@gmail.com

\begin{abstract}
The utilization of media to improve instructing and learning supplements conventional ways to deal with learning. Viable guidance fabricates between understudies' information and the learning destinations in mathematics. Through the using of media, it engages students, aids them in knowledge retention, as well as motivates them. This study assessed the extent of instructional media utilization and the academic performance of the Grade 3 pupils in mathematics in a public elementary school, Cebu City, Philippines. The quantitative research method is being used in the study were data gathered through a variety of measurements treated, including the approval letter, parent's consent, and the respondent's survey checklist. The study revealed that teachers do not fully utilize the library and the audiovisual room of the school. It was concluded that the academic performance of the pupils are not based on how the teacher utilized the instructional media. The researchers recommend that the proposed enhancement plan be used and monitored.
\end{abstract}

Keywords: academic performance, instructional media, learning mathematics

\section{INTRODUCTION}

Technology is everywhere in education. It helps teachers and learners because it has become knowledge transfer in most countries. Technology integration nowadays has gone through innovations and transformed societies that change the way people think, work and live. According to Etcuban et al. (2019), the computer revolution is at hand. A computer is a tool, which may have multiple uses in the mathematics classroom. It may be a device for making the learning of concepts, skills, and problem solving more effective than that of traditional practice. According to King (2000), technology in the hands of great teachers is transformational. It cannot work itself but if a teacher uses it who has skills and knowledge the learning would be meaningful (Kirschner et al., 2006). It is the strategies of the teacher on how to manipulate or transform technology in order for the students to have efficient learning.

Innovation has affected pretty much every part of life today, and training is no particular case. Innovation has significantly changed training. It has enormously extended access to instruction. Open doors for correspondence and cooperation have additionally been extended by innovation. It has likewise started to change the jobs of instructors and students. In the conventional study hall, for example, what we see the educator is the essential wellspring of data, and the students latently get it. The educator fills in as the sage on the stage has been in training for quite a while, and today is still primarily in proof. Be that as it may, due to the entrance to data and instructive open door that innovation has empowered in numerous study halls

Article History: Received 13 May 2019 • Revised 22 May 2019 • Accepted 23 May 2019

(C) 2019 by the authors; licensee Modestum Ltd., UK. Open Access terms of the Creative Commons Attribution 4.0 International License (http://creativecommons.org/licenses/by/4.0/) apply. The license permits unrestricted use, distribution, and reproduction in any medium, on the condition that users give exact credit to the original author(s) and the source, provide a link to the Creative Commons license, and indicate if they made any changes. 
today, we see the educator's job moving to the guide as an afterthought as understudies assume greater liability to their learning using technology to gather relevant information.

In today's classroom, teachers have more tools to help students understand mathematical concepts and a balanced of traditional and modern methods of teaching can help students of all abilities. Technologies are essential in teaching and learning mathematics; they influence what is taught and enhances students' learning. Mathematics is not only a subject; it relates to many things in human's daily life. Its study provides students with sure basic life, skills, and processes that will prepare them to be productive members of society. Proper and coordinated utilization of innovation impacts each aspect of mathematics education: what mathematics taught, how mathematics taught and learn, and how mathematics is assessed. Changes in mathematics including the use of technology have been advocated for several years. The teachers who use materials to enhance their classroom such as computers, calculators, and other technology along with concrete materials can connect materials with effective and developmentally appropriate tasks in which students can engage - learning mathematics with technology engaging students in more active mathematical practices such as experimenting, analyzing, reasoning, problem-solving.

\section{RELATED LITERATURE}

In this time of globalization and innovative upset, instruction is considered as an initial step for each human movement. It assumes an essential job in the improvement of human capital and is connected with a person's prosperity and open doors for better living. It guarantees the obtaining of learning and aptitudes that empower people to expand their efficiency and improve their satisfaction. This expansion in efficiency likewise leads towards new wellsprings of gaining which upgrades the commercial development of a nation.

It is intended for affecting locally, territorially, broadly and all-inclusive. Instructors, mentors, and analysts have for some time been keen on investigating factors contributing successfully for nature of execution of students (Azhar et al., 2014; Meyer, 2002; Stronge, 2018). These factors are inside and outside school that influences understudies' nature of academic accomplishment (Farooq et al., 2011; Zhao \& Kuh, 2004). These components might be named as understudy factors, family factors, school factors, and companion factors. The formal examination about the job of these statistic factors established back in the seventeenth century (Azhar et al., 2014; Farooq et al., 2011). For the most part, these elements incorporate age, sex, land belongingness, ethnicity, marital status, financial status (SES), guardians' instruction level, parental calling, language, pay and religious affiliations (Farooq et al., 2011; Janssen et al., 2006).

In more extensive setting demography is alluded to as an approach to investigate the nature and impacts of statistic factors in the organic and social setting. Tragically, characterizing and estimating the nature of training is certainly not a fundamental issue and the multifaceted nature of this procedure increments because of the changing estimations of value traits related with the various partners' perspective (Stensaker, 2007). Other than different components, financial status is a standout amongst the most investigated and discussed factors among instructive experts that contribute towards the scholarly exhibition of understudies (Jimerson et al., 2002; Marks, 2000; Sirin, 2005). The most common contention is that the financial status of students influences the nature of their scholarly exhibition. The majority of the specialists contend that the low financial status hurts the scholarly exhibition of understudies because the essential needs of understudies stay unfulfilled and subsequently, they do not perform better scholastically. The low financial status causes ecological lacks, which results in low confidence of understudies.

As indicated by Oshinaike and Adekunnmisi (2012), Multimedia is currently penetrating the instructive framework as a device for powerful educating and learning. With media, the correspondence of data should be possible in a progressively successful way, and it tends to be a compelling instructional vehicle for conveying data (Neo \& Neo, 2004; Zhang et al., 2006). Media access to information is one of the potential outcomes of data and correspondence innovation that has a significant effect on learning. The instructional media have risen in an assortment of assets, and gear, which can be utilized to enhance or supplement the instructors' endeavors in guaranteeing compelling learning by understudies. As indicated by Bates (2005), it is perceived that customary media innovations can never again address the issues of instructing and learning forms; accordingly, they are being supplanted by interactive media innovation. This innovation gives a learning domain that is self-guided, student controlled and individualized.

The advancement of sight and sound has made it genuinely feasible for students to turn out to be increasingly associated with their work. With interactive media advancements, they can make sight and sound applications as a component of their venture necessities. This would make them a dynamic member in their 
very own learning procedure, rather than merely being aloof students of the instructive substance. Interactive media in Education has been very viable in showing people a full scope of subjects (Gros, 2007). Media is changing how we speak with one another (Cope \& Kalantzis, 2005; Neo, 2007). How we send and get messages is all the more successfully improved grasped. While an address can be amazingly instructive, an address that coordinates pictures or video picture check help an individual learns and holds data considerably more adequately. Utilizing creative innovations, it very well may be incredibly successful in showing understudies a wide assortment of controls.

Al-Khalifah (1994) investigates the advantage and utilization of varying media materials by instructors and teachers in Kuwait. The instructive framework in Kuwait has depended upon common showing styles, which are fundamentally founded on the utilization of printed writings, with almost no free or asset-based learning. These methodologies may not address the issues all things considered, and the arrangement of multimedia assets in numerous different nations. Teachers were met about their utilization of varying media materials, their perspectives on the points of interest for educating, and the issues experienced in distinguishing and acquiring flexible materials. They gave guides to demonstrate how different media materials had advanced a particular exercise. Instructors were met about their utilization of varying media when showing understudy educators. The understudy instructors were gotten some information about their reaction to the utilization of varying media materials by their teachers, and about their experience of going to seminars on strategies.

The investigation of Bodovski and Farkas (2007) discovered those understudies who started with the most minimal accomplishment likewise demonstrated minimal development over the period. Understudies in the two most astounding abilities bunches had comparative development and the most significant amounts of development. Understudies in the least gathering got the most time on guidance however had the most reduced commitment with guidance. Time on guidance expanded accomplishment for all understudies similarly, yet the impact of commitment was most grounded among the lowest-performing gathering. The lower commitment of the lowest-performing bunch clarified the more significant part of their lower accomplishment development in evaluations K-3. If an imbalance in science accomplishment is to be decreased, educators must try more prominent endeavors to improve the starting information and scholastic commitment of this gathering.

As per Moyer (2001) that instructors frequently remark that utilizing manipulatives to train science is enjoyable! Installed in the word 'fun' are significant thoughts about how and why educators use manipulatives in the instructing of science. An examination of the members' announcements and practices showed that utilizing manipulatives was minimal more than a preoccupation in study halls where educators were not ready to speak to arithmetic ideas themselves. The educators conveyed that the manipulatives were fun, yet a bit much, for instructing and learning arithmetic.

Current astuteness proposes that achieving the progressions reformers call for in arithmetic instructing will require tremendous learning concerning educators. Examinations over the cases uncovered essential exercises engaged with instructing and utilizing writings that made open doors for learning. These exercises included examining understudies and scientific assignments and settling on choices about how to continue, proposing that materials well on the way to encourage educator learning are those that connect with instructors in these procedures (Remillard, 2000).

In 2011, the Philippine government set up a national procedure for improving Internet get to, recognizing training as a critical territory that would profit by data and correspondences innovation (ICT) advancement (Bertot et al., 2010; Gulati, 2008). Among the objectives were that 100 percent of auxiliary schools and 80 percent of primary schools in the nation ought to have Internet access by 2016. The presence of methodologies and entrances are insufficient. Next comes the more substantial test of conveying these assets to schoolchildren. The Philippines' Department of Education (DepEd) perceives the critical job of ICT in improving the condition of instruction. The Internet, with its ability to hold a vast number of assets, can give extensive and far-reaching training to understudies, wherever they might be in the nation. Web-based learning databases do not squander valuable characteristic assets. A single PC and projector set-up, for instance, can be utilized for a learning session for a whole study hall.

Instead of books and papers, understudies can get to modules, submit assignments, and counsel with their instructors and schoolmates on the web. Educators can likewise profit by learning devices that do not require conventional coordinations and various materials. For instance, the DepEd has propelled the Learning Resources Management and Development System (LRMDS), an entryway for an Internet instructing and 
learning materials made by educators and training accomplices. This program will enable our students to have more access to relevant, forward-thinking and quality instructional materials. It likewise gives a database to our teachers where they can determine their exercises. These materials will help them in their exercise designs, and may likewise give a variety of contextualized homeroom discourses.

The family unit media condition is altogether connected with understudies' presentation on the government-sanctioned tests. It was found in the investigation of Borzekowski and Robinson (2005) that having a room TV was fundamentally and contrarily connected with understudies' test scores, while home PC access and use were decidedly connected with the scores. Relapse models fundamentally anticipated up to $24 \%$ of the variety in the scores. Nonattendance of a room TV joined with access to a home PC was reliably connected with the most astounding government sanctioned test scores.

These literature have contributed to the formulation on how to facilitate learning in mathematics in public elementary schools in the Philippines.

\section{OBJECTIVES OF THE STUDY}

The study assessed the extent of instructional media utilization and the academic performance of the Grade 3 pupils in mathematics in a public elementary school, Cebu City, Philippines. It answered the: 1) Profile of the learners; 2) Level of academic performance of the learners; 3) Extent use of the instructional media as utilized by their teachers; 4) Significant relationship between the instructional media utilization and the academic performance of the respondents.

\section{METHODOLOGY}

This study employed the descriptive method to gather data on the assessment of the Grade 3 pupils in the use of instructional materials in facilitating learning Mathematics and their academic performance. It was conducted in one of the most prominent public elementary school in the Division of Cebu City, Philippines. Though a small number of instructional media such as audiovisual, library, multipurpose areas and instructional materials are available. The respondents of this study were the Grade III pupils of Lahug Elementary School. The researchers prompted to assess the utilization of Instructional Media in teaching Mathematics on how it affects their academic performances. Thirty respondents are selected using nonprobability purposive sampling. They are asked by the researchers for consent and approval to answer the survey questionnaire. The study used an adapted questionnaire checklist by Kenneth C. Bandajon in his study entitled "Media Utilization and Academic Achievement of Grade VI Pupils." The instrument has four components namely: Instructional Materials, Library, Audio-Visual, and Multipurpose Areas. Its magazines, graphs, maps, pictures, and others gave useful information on how frequent the teacher utilized instructional media. They answered the instrument using the 3-point scale, 3 points for always utilized, 2 points for sometimes utilized, and 1 point for never utilized. The gathered data were statistically treated using frequency, simple percentage, weighted mean, and Pearson r.

\section{RESULTS AND DISCUSSIONS}

Given the outcomes and discoveries of the examination, it very well may be presumed that the respondents got a normal of 84.8 , it implies that they had an attractive execution in mathematics. As per the consequences of the overview directed by the researchers, among the four instructional media that are mentioned, Instructional Materials got the highest utilized which means that the teacher used it in conducting his or her lessons while the library got the least utilized, which means that the teacher did not use the library as his or her primary source in teaching. Due to this matter, the researchers find that there is no significant relationship between the learners' academic performance and the utilization of instructional media.

Table 1. Age and Gender of the Respondents

\begin{tabular}{ccccccc}
\hline & \multicolumn{2}{c}{$\begin{array}{c}\text { Male } \\
(\mathbf{n}=\mathbf{1 2})\end{array}$} & \multicolumn{2}{c}{$\begin{array}{c}\text { Female } \\
(\mathbf{n}=\mathbf{1 8})\end{array}$} & \multicolumn{2}{c}{$\begin{array}{c}\text { Total } \\
(\mathbf{n}=\mathbf{3 0})\end{array}$} \\
\hline Age (in yrs) & Frequency & Percentage & Frequency & Percentage & Frequency & Percentage \\
\hline 9 & 2 & 6.67 & 5 & 16.66 & 7 & 23.33 \\
\hline 8 & 10 & 33.33 & 13 & 43.33 & 23 & 76.67 \\
\hline Average : & $\mathbf{8 . 2}$ & & $\mathbf{8 . 3}$ & & $\mathbf{8 . 2}$ & \\
\hline
\end{tabular}


Given the table, a large portion of the respondents was aging eight years old wherein the average age for male and female respondents was 8.2 and 8.3 years old respectively. It can determine that the males are younger than the female respondents. However, their age is appropriate for Grade 3 pupils in the Philippines were the overall average of the respondents was 8.2 years old. This indicates that most of the respondents started schooling at the right age and were not stopped schooling in their early grade levels. Even though there were respondents who are younger than their expected age, they only contain the seven (7) or 23.33 percent out of the total respondents. This implies beginning school more youthful methods completing school at a more youthful age, which infers more opportunity for the person to procure returns on their interest in instruction. Beginning school more youthful may likewise be profitable to the degree that youngsters adapt more at school than at home.

As indicated by Broussard and Garrison (2004) that the connection between inspiration and scholarly achievement has been exceptional set up with more established kids and grown-ups than with more youthful youngsters. The discoveries from the momentum contemplate predictable with past research in that more elevated amounts of dominance inspiration and judgment inspiration were observed to be identified with higher math and perusing grades in third graders. Be that as it may, more significant amounts of authority inspiration, not judgment inspiration, were identified with higher math and perusing grades in elementary graders.

Table 2. Performance Level of the Respondents

\begin{tabular}{lccc}
\hline Level & Grade & Frequency & Percentage \\
\hline Outstanding & $90-100$ & 8 & 26.67 \\
\hline Very Satisfactory & $85-89$ & 11 & 36.67 \\
\hline Satisfactory & $80-84$ & 5 & 16.66 \\
\hline Fair Satisfactory & $75-79$ & 6 & 20.00 \\
\hline Did not meet the expectations & Below 75 & 0 & 0.00 \\
\hline Average : & $\mathbf{8 4 . 8}$ & & \\
\hline
\end{tabular}

Based on the table, the respondents had a satisfactory performance with an average grade of 84.8 . These data recommend that the performance of the respondents need to be enhanced for them to reach the very satisfactory. If there is no action taken to this situation, there is a possibility that some of the respondents who are belonging to satisfactory performance will decrease and some will fail in the succeeding quarters. Thus, it is essential to maximize the activities that could help the learners to enhance their skills in mathematics.

According to Strong et al. (2005), academic success or achievement is significant because it is strongly linked to the positive outcomes we value and for the successful development of young people in society.

Consequences of the investigation of Woodward (2006) demonstrated that the two methodologies were compelling in helping understudies accomplish automaticity in duplication certainties. In any case, understudies in the incorporated methodology by and large performed better on posttest and support test estimates that evaluated the use of certainties to broadened realities and guess assignments. These outcomes have suggestions for showing a scope of abilities and ideas that are viewed as critical to by and sizeable numerical skill in the initial evaluations.

The investigation of Howie (2003) uncovered that various other foundation factors on understudy and classlevel were observed to be noteworthy. Nonetheless, the class measure was among those that were not found to have a massive impact on accomplishment, while the impact of financial status had a lesser impact once certain class-level elements were contemplated.

The investigation of Matějů and Smith (2015) looks at sexual orientation holes in scholastic execution of grade schools in the Czech Republic. It was discovered that young ladies firmly outflank young men. Additionally, it was discovered that sexual orientation predisposition in arithmetic evaluations, in the wake of controlling for estimated capacity and different variables.

The investigation of Valås (2001) manages relations between scholastic accomplishment, learned weakness and mental modification (confidence and sorrow), controlled for sexual orientation and age. The examinations of basic condition models demonstrated that scholarly accomplishment was straightforwardly and in a roundabout way identified with the example of attributions, desires, powerlessness, and mental modification. Also, powerlessness and scholarly desires were altogether identified with mental modification. The outcomes likewise obviously discovered that young men indicated progressively vulnerable conduct, as surveyed by the 
instructor, then did young ladies, while, then again, young ladies revealed increasingly mental maladjustment.

Table 3. Perceived Use of the School Library

\begin{tabular}{llcc}
\multicolumn{1}{c}{ Indicators } & Mean & StDev & $\begin{array}{c}\text { Verbal } \\
\text { Description }\end{array}$ \\
\hline $\begin{array}{l}\text { 1. The teacher is using the prescribed textbooks found in the library } \\
\text { 2. The teacher is using other available books and other references in the } \\
\text { library. }\end{array}$ & 1.70 & 0.702 & Utilized \\
\hline $\begin{array}{l}\text { 3. The teacher brings the class as part of their orientation. } \\
\text { 4. The teacher together with the class has visiting schedules in the } \\
\text { library. }\end{array}$ & 1.87 & 0.834 & Utilized \\
\hline $\begin{array}{l}\text { 5. The teacher explains the importance, and the proper use of the library } \\
\text { or at least allows the librarian to explain the value of the library. }\end{array}$ & 1.73 & 0.907 & Not Utilized \\
\hline $\begin{array}{l}\text { The teacher instructs pupils in borrowing books for research and } \\
\text { instruction. }\end{array}$ & 1.43 & 0.504 & Not Utilized \\
\hline $\begin{array}{l}\text { 7. The teacher instructs the class to go to the library to study during } \\
\text { vacant hours. }\end{array}$ & 1.17 & 0.531 & Not Utilized \\
\hline $\begin{array}{l}\text { 8. The teacher is using library materials like atlases, maps, journals, and } \\
\text { pictures to supplement the instructions. }\end{array}$ & 1.97 & 0.765 & Utilized \\
\hline $\begin{array}{l}\text { 9. The teacher gives assignments that require the use of the library. } \\
\text { 10. The teacher is found in the library together with the pupils. }\end{array}$ & 1.27 & 0.450 & Not Utilized \\
\hline & $\mathbf{1 . 4 7}$ & 0.484 & Not Utilized \\
\hline
\end{tabular}

Based on the table, among the four components of Instructional Media, library utilization got the lease overall weighted mean of 1.47, which interpreted as not utilized. This means that the teacher is not using the library as her or his primary source in teaching the pupils. The result indicates that the extent of library utilization of the teacher in teaching mathematics is not that useful or not utilized. A library facilitates the planning and implementation of learning programs that will equip the students with the aptitudes and information essential to prevail in a continually changing social and economic environment. Through resourcebased programs, students acquire skills to collect, critically analyze and organize information, solve the problem and communicate their understandings.

Neuman (2002), previous methods of counting used in libraries have been based on circulation figureshow often children and their families check out books. In many library systems across the country, this figure will be used to determine budget allocations for the next year, leading to some libraries to have larger budgets than others. Libraries in deprived areas have dramatically lower counts than middle-income.

The study of Aabø and Audunson (2012) found out that the open library use is hugely different. Supporters move effectively among high and low dangerous exercises and buoy between life circles and jobs-understudy, relative, companion, neighbor, and native. The library is an unpredictable field. It is an open domain, as in the more significant part of the guests are outsiders to one another; the more significant part of the individual users have a place with a private domain, and the library's locale exercises comprise it as a parochial domain. In the library, clients are presented to the majority of the network and find out about otherness. Individuals are not ordered by calling or as being jobless, a patient or a customer, yet are all library clients. This nature of the library adds to social incorporation.

Pihil (2012) investigates the inquiries to what degree instructive research tends to library use in training and how the library can add to intercultural training. The emphasis is basically on basic instruction in Europe. The discoveries demonstrate that exploration on library use and library assets is under-looked into in instructive research, including instructive intercultural research. The audit and observational investigations demonstrate that training dependent on the utilization of library assets can help acknowledge significant points of intercultural instruction including arrangement of non-isolated instruction, improvement of perusing commitment and proficiency accomplishment among first and second language students that surpasses that inside conventional proficiency programs, multilingual advancement, incorporation of data education in substance learning, strengthening of understudies as capable library clients, and intercultural training dependent on assorted substance learning inside expressions, sociologies, and characteristic sciences. Notwithstanding, instructors and principals need to team up with curators to understand these points.

The investigation of Valås (2001) manages relations between scholastic accomplishment, learned defenselessness and mental modification (confidence and gloom), controlled for sex and age. The examinations 
of basic condition models demonstrated that academic accomplishment was straightforwardly and in a roundabout way identified with the example of attributions, desires, defenselessness, and mental alteration. Also, defenselessness and scholarly desires were altogether identified with mental modification. The outcomes likewise plainly discovered that young men demonstrated increasingly defenseless conduct, as evaluated by the educator, then did young ladies, while, then again, young ladies announced progressively mental maladjustment.

Table 4. Perceived Use of the Audiovisual

\begin{tabular}{|c|c|c|c|}
\hline Indicators & Mean & StDev & $\begin{array}{c}\text { Verbal } \\
\text { Description }\end{array}$ \\
\hline $\begin{array}{l}\text { 1. The teacher is using cassette tapes, karaoke as an aid in teaching the } \\
\text { different lessons. }\end{array}$ & 1.40 & 0.675 & Not Utilized \\
\hline $\begin{array}{l}\text { 2. The teacher is using recorded tapes/ sounds/ conversations to provide } \\
\text { more information and entertainment. }\end{array}$ & 1.43 & 0.626 & Not Utilized \\
\hline 3. The teacher is using television as instructional materials. & 1.97 & 0.414 & Utilized \\
\hline 4. The teacher is using CD or DVD players to play films or movies. & & 0.679 & Not Utilized \\
\hline $\begin{array}{l}\text { 5. The teacher is using educational films Sineskwela, Hiyaramaniwari and } \\
\text { the like. }\end{array}$ & 1.87 & 0.681 & Utilized \\
\hline 6. The teacher is using an overhead projector in the discussion. & 1.57 & 0.774 & Not Utilized \\
\hline 7. The teacher is using LCD or electronic projection. & 7 & 0.858 & Utilized \\
\hline 8. The teacher is using a computer to facilitate learning. & 1.63 & 0.765 & Not Utilized \\
\hline 9. The teacher is using a microphone and speaker in the sound discussion. & 1.27 & 0.521 & Not Utilized \\
\hline $\begin{array}{l}\text { 10.The teacher is using computer programs (spelling, IQ, adventure, } \\
\text { puzzle) to facilitate learning. }\end{array}$ & 1.30 & 0.535 & Not Utilized \\
\hline Over & 1.56 & 0.653 & Not Utilized \\
\hline
\end{tabular}

Based on the table, the overall weighted mean of the extent in audiovisual utilization with an average of 1.56, which interpreted as not utilized. This means that the teacher is seldom using audiovisual materials or things that are also useful in teaching or presenting her/his lessons. Muliani (2018) audio-visual aids are a useful tool that invests the past with an air of reality.

The study of Al-Khalifah (1994) concludes that the use of audiovisual materials in teaching benefits both teachers and learners by making concepts easily understandable, overcoming physical difficulties, and stimulating enjoyment, confidence, concentration, and teacher/learner communication. There are problems in the procurement, and use of audiovisual materials and educational technology supervisors in many of the surveyed schools were considered by teachers to be a source of support if adequately trained and wisely used.

The study of Bennett and Lockyer (2008) found that elementary pupils used interactive whiteboards (IWBs) to a shifting degree through the span of a showing week, with exercises that incorporated the utilization of IWBs tending to concentrate on education and numeracy. The innovation was promptly fused into the study hall condition by instructors and thought about simple to utilize. Instructors embraced a scope of educational methodologies when utilizing the IWBs and these methodologies were predictable with those they typically utilized in their instructing.

Table 5. Perceived Use of the Multipurpose Areas

\begin{tabular}{llcc}
\multicolumn{1}{c}{ Indicators } & Mean & StDev $\begin{array}{c}\text { Verbal } \\
\text { Description }\end{array}$ \\
\hline $\begin{array}{l}\text { 1. } \\
\text { The teacher is using an area for Parent-Teacher and Community } \\
\text { assembles. }\end{array}$ & 1.80 & 0.714 & Utilized \\
\hline $\begin{array}{l}\text { The teacher is using an area served as a place for small group conferences } \\
\text { for Science and Math members and other clubs etc. }\end{array}$ & 2.10 & 0.712 & Utilized \\
\hline $\begin{array}{l}\text { The teacher is using an area that serves as a place for school faculty } \\
\text { meetings to discuss the program and other school-related activities. }\end{array}$ & 2.00 & 0.643 & Utilized \\
\hline $\begin{array}{l}\text { The teacher is using an area utilized as a place to district meetings and } \\
\text { school meetings. }\end{array}$ & 1.87 & 0.681 & Utilized \\
\hline $\begin{array}{l}\text { The teacher is using an area served as a place for the district and school } \\
\text { contests such as science fair and quiz bee, conventions and the like. }\end{array}$ & 2.10 & 0.607 & Utilized \\
\hline
\end{tabular}

Looking closely at the table, the study got the highest weighted mean with an average of 2.10, which interpreted as utilized. This means that the teacher is using an area served as a place for small group conferences for Science and Math members and other clubs and also using an area served as a place for the 
district and school contests such as science fair and quiz bee, conventions and the like. In general, among the four components, the extent of multipurpose areas got the all utilized rate with the average weighted mean of 1.97 and interpreted as utilized. This means that the teacher is using multipurpose areas in school. Multipurpose stadiums have many different types of customers, including sponsors, employees, suppliers and the communities in which they operate (Guenzi, 2012; Roy, 2008).

According to Bentsen et al. (2013) that more and more instructors have begun presenting educational programs based on outdoor learning as week by week or fortnightly 'outside school' day for younger students. This move towards tutoring in non-homeroom spaces shows a test for green space supervisors. Necessary administrative information identified with what, who, when and where has hitherto just been bolstered by narrative proof, however, appears to be crucial to the necessary leadership of scope of green space suppliers. The instructors utilized fundamentally school grounds and neighborhood green space for they are outside educating with a dominant part utilizing a similar spot or for the most part a similar spot and leaning toward typical habitats with simple access.

Graber et al. (2008) say that elementary school has repeatedly been shaped by the forces of history, which provide readers with information about the social context and present status. Attention is given to the effect of national recommendations from government agencies, newly devised standards from professional organizations, new legislative mandates, experimental trials of sustainable in-service education, and the role of research in shaping both pedagogy and curriculum.

Table 6. Perceived Use of the Instructional Materials

\begin{tabular}{llcc}
\multicolumn{1}{c}{ Indicators } & Mean & StDev & $\begin{array}{c}\text { Verbal } \\
\text { Description }\end{array}$ \\
\hline $\begin{array}{l}\text { 1. The teacher is using Instructional Materials like pictures, graphs, } \\
\text { map, and real objects in teaching. }\end{array}$ & 2.33 & 0.606 & Utilized \\
\hline $\begin{array}{l}\text { 2. The teacher is using recyclable and reusable materials like } \\
\text { newspapers, bottles, magazines, and plastics. }\end{array}$ & 1.40 & 0.563 & Not Utilized \\
\hline $\begin{array}{l}\text { The teacher is using Instructional Materials to facilitate fun and } \\
\text { exciting learning. }\end{array}$ & 2.10 & 0.607 & Utilized \\
\hline $\begin{array}{l}\text { 4. The teacher is using varied Instructional Materials that appropriate } \\
\text { to the lessons. }\end{array}$ & 2.63 & 0.556 & $\begin{array}{c}\text { Highly } \\
\text { Utilized }\end{array}$ \\
\hline $\begin{array}{l}\text { The teacher is using ready-to-use Instructional Materials available in } \\
\text { schools like TV, cassette player, and DVD player. }\end{array}$ & 2.03 & 0.556 & Utilized \\
\hline $\begin{array}{l}\text { The teacher explains the value and importance of Instructional } \\
\text { Materials before using. }\end{array}$ & 2.67 & 0.606 & $\begin{array}{c}\text { Highly } \\
\text { Utilized }\end{array}$ \\
\hline $\begin{array}{l}\text { 7he teacher allows the pupils to manipulate or to hold the } \\
\text { Instructional Materials to promote hands-on training. }\end{array}$ & 2.23 & 0.679 & Utilized \\
\hline $\begin{array}{l}\text { The teacher explains well the lessons thru the use of Instructional } \\
\text { Materials. }\end{array}$ & 2.53 & 0.819 & $\begin{array}{c}\text { Highly } \\
\text { Utilized }\end{array}$ \\
\hline $\begin{array}{l}\text { 9. The teacher handles the Instructional Materials with utmost care. } \\
\text { 10. The teacher requires the class to use recyclable materials in doing } \\
\text { projects or presenting reports. }\end{array}$ & 2.67 & 0.661 & $\begin{array}{c}\text { Highly } \\
\text { Utilized }\end{array}$ \\
\hline
\end{tabular}

In light of the figures appeared in the table that among the four components of instructional media the extent of Instructional Materials got the highest overall weighted mean with an average of 2.27, which interpreted as utilized. This means that the teacher always using Instructional Materials in teaching his or her pupils. Instructional materials play an essential role in the school curriculum as they contain the content of a subject matter.

The findings of the study of Collopy (2003) indicated that thought of the cooperation between convictions fundamental to instructors' personality and those that are focused for change might light up reactions to possibly educative educational programs materials.

The study of Goos and Bennison (2004) reported that factors such as access, attitudes, an opportunity to learn how to use technology must be utilized inside the classroom. Although the schools appeared to be providing access to instructional media, merely having these resources available does not mean that teachers and students can use them whenever appropriate or necessary. Many students without continuous personal access to these materials have difficulties in utilizing. In any case, it is a slip-up to accept that essentially 
providing schools with instructional materials will build instructors' utilization of innovation and empower increasingly inventive educating approaches.

As indicated by Fuller (1987) that inside industrialized nations, much is thought about the connection between schools' real sources of info or social practices and students' accomplishment levels. Less is thought about school impacts in creating nations. In the Third World, the typical school is frequently a new foundation, working in social settings where composed proficiency and formal socialization are generally ongoing marvels. Along these lines, even schools with constrained physical assets seem to strongly affect scholastic accomplishment, free of understudies' family foundation, and inside industrialized nations. This hopeful case is undermined, nonetheless, by impediments in how student foundation qualities have been indicated inside exact models.

As shown in Table 7, the test on instructional media utilization and the academic performance had a computed r-value of negative 0.027 , which means that there is a negative correlation between the instructional media utilization and the academic performances of the respondents. However, the test for the significance of their relationship revealed that $\mathrm{p}$-value of 0.888 is higher than the essentialness dimension of 0.05 (0.888 > 0.05 ), which means that the null hypothesis is not rejected.

Table 7. Significant Relationship Between Instructional Media Utilization and Academic Performance

\begin{tabular}{lcccccc}
\hline Variables & n & Pearson r & Strength & p-Value & Decision & Remarks \\
\hline $\begin{array}{l}\text { Instructional Media } \\
\text { Utilization and Academic }\end{array}$ & 30 & -0.027 & $\begin{array}{c}\text { Little } \\
\text { Correlation }\end{array}$ & 0.888 & Accept Ho & $\begin{array}{c}\text { Not } \\
\text { Serformificant }\end{array}$ \\
Permance & & & &
\end{tabular}

*significant at $p<0.05$ (two-tailed)

These suggest that the significant relationship between instructional media utilization and academic performance. Technology cannot work itself but if a teacher uses it who has skills and knowledge the learning would be meaningful. It is the strategies of the teacher on how to manipulate or transform technology in order for the students to have efficient learning.

According to Guerrero et al. (2004) that the use of technology in middle-grade mathematics is controversial. Original approach records have educators torn between excitement for innovation encouraged scientific examination and alerts about undermining understudies' computational abilities. The examination surveyed identifies with instructors' innovation experience, educator and understudy frames of mind, innovation execution patterns, and impacts of innovation on understudies' aptitudes and calculated comprehension. At the point when innovation is utilized well in science, it can affect understudies' mentalities toward learning, trust in their capacities to do arithmetic, commitment with the topic, and scientific accomplishment and reasonable comprehension. The degree to which this potential is acknowledged relies upon the instructor's aptitude in incorporating innovation into the science educational modules as indicated by sound academic standards. Cautious thoughtfulness regarding educator readiness and improvement, just as educational programs update, is expected to help compelling utilization of innovation in mathematics.

$\mathrm{Li}$ and $\mathrm{Ma}$ (2010) say that several characteristics of primary studies were identified as having effects. Instructional media showed an advantage in promoting mathematics achievement of elementary students. It showed more significant effects on mathematics achievement when combined with a constructivist approach to teaching than with a traditional approach to teaching.

\section{CONCLUSIONS}

With the conclusion, that there is no significant relationship between instructional media utilization and the academic performance of the respondents because the academic performance of the pupils are not based on how the teacher utilized the instructional media, opens another avenue of intellectual discourse of the effectivity of technology among pupils of a developing country like the Philippines. When students feel empowered in their learning through the usage of technology, they are more likely to accept ownership of it. If a teacher delivers the material to the students through lecture, they may feel no attachment to it. This research gives a sturdy articulation of how technology can be appropriately used in the andragogy and pedagogy. 


\section{RECOMMENDATIONS}

The researchers recommend that teachers must always use Instructional Media as part of their motivation, presentation, discussion, and evaluation of the lesson to make meaningful learning to the pupils. Also, they recommend that the proposed enhancement be used and monitored.

\section{Disclosure statement}

No potential conflict of interest was reported by the authors.

\section{Notes on contributors}

Reylan Capuno - Cebu Technological University, Cebu City, Philippines.

Helen Revalde - Cebu Technological University, Cebu City, Philippines.

Jonathan Olores Etcuban - Cebu Technological University, Cebu City, Philippines.

Marvin Aventuna - Cebu Technological University, Cebu City, Philippines.

Gerwine Medio - Cebu Technological University, Cebu City, Philippines.

Rino Anthony Demeterio - Cebu Technological University, Cebu City, Philippines.

\section{REFERENCES}

Aabø, S., \& Audunson, R. (2012). Use of library space and the library as place. Library \& Information Science Research, 34(2), 138-149. https://doi.org/10.1016/j.lisr.2011.06.002

Al-Khalifah, A. J. (1994). Teachers' use of audiovisual media for teaching and learning in Kuwait public schools, the influence of teacher training colleges and the role of the school library in media provision (Doctoral dissertation, C Ahmad J. Al-Khalifah). Retrieved from http://bit.ly/2Ynh3P9

Azhar, M., Nadeem, S., Naz, F., Perveen, F., \& Sameen, A. (2014). Impact of parental education and socioeconomic status on academic achievements of university students. European Journal of Psychological Research, 1(1). Retrieved from http://bit.ly/30eepN1

Bates, A. T. (2005). Technology, e-learning and distance education. Routledge. https://doi.org/10.4324/9780203463772

Bennett, S., \& Lockyer, L. (2008). A study of teachers' integration of interactive whiteboards into four Australian primary school classrooms. Learning, Media and Technology, 33(4), 289-300. https://doi.org/10.1080/17439880802497008

Bentsen, P., Schipperijn, J., \& Jensen, F. S. (2013). Green space as classroom: Outdoor school teachers' use, preferences, and eco-strategies. Landscape Research, 38(5), 561-575. https://doi.org/10.1080/01426397.2012.690860

Bertot, J. C., Jaeger, P. T., \& Grimes, J. M. (2010). Using ICTs to create a culture of transparency: Egovernment and social media as openness and anti-corruption tools for societies. Government Information Quarterly, 27(3), 264-271. https://doi.org/10.1016/j.giq.2010.03.001

Bodovski, K., \& Farkas, G. (2007). Mathematics growth in early elementary school: The roles of beginning knowledge, student engagement, and instruction. The Elementary School Journal, 108(2), 115-130. https://doi.org/10.1086/525550

Borzekowski, D. L., \& Robinson, T. N. (2005). The remote, the mouse, and the no. 2 pencil: the household media environment and academic achievement among third-grade students. Archives of Pediatrics \& Adolescent Medicine, 159(7), 607-613. https://doi.org/10.1001/archpedi.159.7.607

Broussard, S. C., \& Garrison, M. B. (2004). The relationship between classroom motivation and academic achievement in elementary-school-aged children. Family and Consumer Sciences Research Journal, 33(2), 106-120. https://doi.org/10.1177/1077727X04269573

Collopy, R. (2003). Curriculum materials as a professional development tool: How a mathematics textbook affected two teachers' learning. The Elementary School Journal, 103(3), 287-311. https://doi.org/10.1086/499727 
Cope, B., \& Kalantzis, M. (2005). Introduction: Multiliteracies: The beginnings of an idea. In Multiliteracies: Lit Learning (pp. 13-18). Routledge. Retrieved from http://bit.ly/2LFPtLq

Etcuban, J. O., Campanilla, B. S., \& Horteza, A. D. (2019). The use of Mathcad in the achievement of education students in teaching College Algebra in a university. International Electronic Journal of Mathematics Education, 14(2), 341-351. https://doi.org/10.29333/iejme/5718

Farooq, M. S., Chaudhry, A. H., Shafiq, M., \& Berhanu, G. (2011). Factors affecting students' quality of academic performance: A case of secondary school level. Journal of Quality and Technology Management, 7(2), 1-14. Retrieved from http://bit.ly/2YtpI2F

Fuller, B. (1987). What school factors raise achievement in the third world?. Review of Educational Research, 57(3), 255-292. https://doi.org/10.3102/00346543057003255

Goos, M., \& Bennison, A. (2004). Teachers' use of technology in secondary school mathematics classrooms. In the annual conference of the Australian Association for Research in Education, Melbourne (Vol. 28). Retrieved from http://bit.ly/2JIHjj5

Graber, K. C., Locke, L. F., Lambdin, D., \& Solmon, M. A. (2008). The landscape of elementary school physical education. The Elementary School Journal, 108(3), 151-159. https://oi.org/10.1086/529098

Gros, B. (2007). Digital games in education: The design of games-based learning environments. Journal of Research on Technology in Education, 40(1), 23-38. https://doi.org/10.1080/15391523.2007.10782494

Guenzi, P. (2012). Sports marketing and facility management: from stadiums. Marketing and Football, 130. Retrieved from http://bit.ly/2WHsuAW

Guerrero, S., Walker, N., \& Dugdale, S. (2004). Technology in support of middle-grade mathematics: What have we learned? Journal of Computers in Mathematics and Science Teaching, 23(1), 5-20. Retrieved from http://bit.ly/2Q2415g

Gulati, S. (2008). Technology-enhanced learning in developing nations: A review. The International Review of Research in Open and Distributed Learning, 9(1). https://doi.org/10.19173/irrodl.v9i1.477

Howie, S. J. (2003). Language and other background factors affecting secondary pupils' performance in Mathematics in South Africa. African Journal of Research in Mathematics, Science and Technology Education, 7(1), 1-20. https://doi.org/10.1080/10288457.2003.10740545

Janssen, I., Boyce, W. F., Simpson, K., \& Pickett, W. (2006). Influence of individual and area-level measures of socioeconomic status on obesity, unhealthy eating, and physical inactivity in Canadian adolescents. The American Journal of Clinical Nutrition, 83(1), 139-145. https://oi.org/10.1093/ajcn/83.1.139

Jimerson, S. R., Anderson, G. E., \& Whipple, A. D. (2002). Winning the battle and losing the war: Examining the relation between grade retention and dropping out of high school. Psychology in the Schools, 39(4), 441-457. https://doi.org/10.1002/pits.10046

King, K. P. (2000). Educational technology that transforms: Educators' transformational learning experiences in professional development. Retrieved from http://bit.ly/2Ymeehm

Kirschner, P. A., Sweller, J., \& Clark, R. E. (2006). Why minimal guidance during instruction does not work: An analysis of the failure of constructivist, discovery, problem-based, experiential, and inquiry-based teaching. Educational Psychologist, 41(2), 75-86. https://doi.org/10.1207/s15326985ep4102_1

Li, Q., \& Ma, X. (2010). A meta-analysis of the effects of computer technology on school students' mathematics learning. Educational Psychology Review, 22(3), 215-243. https://doi.org/10.1007/s10648-010-9125-8

Marks, H. M. (2000). Student engagement in instructional activity: Patterns in the elementary, middle, and high school years. American Educational Research Journal, 37(1), 153-184. https://doi.org/10.3102/00028312037001153

Matějů, P., \& Smith, M. L. (2015). Are boys that bad? Gender gaps in measured skills, grades, and aspirations in Czech elementary schools. British Journal of Sociology of Education, 36(6), 871-895. https://doi.org/10.1080/01425692.2013.874278

Meyer, K. A. (2002). Quality in distance education: Focus on online learning. ASHE-ERIC Higher Education Report. Jossey-Bass Higher and Adult Education Series. Jossey-Bass, 989 Market Street, San Francisco, CA 94103-1741. Retrieved from http://bit.ly/2HlETUJ

Moyer, P. S. (2001). Are we having fun yet? How teachers use manipulatives to teach mathematics. Educational Studies in Mathematics, 47(2), 175-197. https://doi.org/10.1023/A:1014596316942

Muliani, E. (2018). Audiovisual helping teacher and students in teaching learning process of Social Sciences subject at SDN 024868 Binjai. Vision, 14(14). Retrieved from http://bit.ly/2VjJmfh 
Neo, M. (2007). Learning with multimedia: Engaging students in constructivist learning. International Journal of Instructional Media, 34(2), 149-159. Retrieved from http://bit.ly/2HfEeoU

Neo, T. K., \& Neo, M. (2004). Classroom innovation: Engaging students in interactive multimedia learning. Campus-Wide Information Systems, 21(3), 118-124. https://doi.org/10.1108/10650740410544018

Neuman, S. (2002). The role of school libraries in elementary and secondary education. Teacher LibrarianSeattle, 30, 74-75. Retrieved from http://bit.ly/2VmEHcR

Oshinaike, A. B., \& Adekunmisi, S. R. (2012). Use of multimedia for teaching in Nigerian university system: A case study of University of Ibadan. Library Philosophy and Practice (e-journal), 682. Retrieved from http://bit.ly/2E5gIcd

Pihl, J. (2012). Can library use enhance intercultural education? Retrieved from http://bit.ly/2Jvxo02

Remillard, J. T. (2000). Can curriculum materials support teachers' learning? Two fourth-grade teachers' use of a new mathematics text. The Elementary School Journal, 100(4), 331-350. https://doi.org/10.1086/499645

Roy, D. P. (2008). Impact of new minor league baseball stadiums on game attendance. Sport Marketing Quarterly, 17(3), 146. Retrieved from http://bit.ly/2PZQxIJ

Sirin, S. R. (2005). Socioeconomic status and academic achievement: A meta-analytic review of research. Review of Educational Research, 75(3), 417-453. https://doi.org/10.3102/00346543075003417

Stensaker, B. (2007). Quality as fashion: Exploring the translation of a management idea into higher education. Quality Assurance in Higher Education (pp. 99-118). Springer, Dordrecht. https://doi.org/10.1007/978-1-4020-6012-0_4

Strong, W. B., Malina, R. M., Blimkie, C. J., Daniels, S. R., Dishman, R. K., Gutin, B., ... Rowland, T. (2005). Evidence-based physical activity for school-age youth. The Journal of Pediatrics, 146(6), 732-737. https://doi.org/10.1016/j.jpeds.2005.01.055

Stronge, J. H. (2018). Qualities of effective teachers. ASCD. Retrieved from http://bit.ly/2VihNTy

Valås, H. (2001). Learned helplessness and psychological adjustment: Effects of age, gender, and academic achievement. Scandinavian Journal of Educational Research, 45(1), 71-90. https://doi.org/10.1080/00313830020042689

Woodward, J. (2006). Developing automaticity in multiplication facts: Integrating strategy instruction with timed practice drills. Learning Disability Quarterly, 29(4), 269-289. https://doi.org/10.2307/30035554

Zhang, D., Zhou, L., Briggs, R. O., \& Nunamaker Jr, J. F. (2006). Instructional video in e-learning: Assessing the impact of interactive video on learning effectiveness. Information \& Management, 43(1), 15-27. https://doi.org/10.1016/j.im.2005.01.004

Zhao, C. M., \& Kuh, G. D. (2004). Adding value: Learning communities and student engagement. Research in Higher Education, 45(2), 115-138. https://doi.org/10.1023/B:RIHE.0000015692.88534.de 